\title{
A survey of major weeds grown in marginal and cultivated lands of Bani Al-Hareth area, Sana'a, Yemen.
}

\author{
*Kulaib, J. F. M \\ *Dept. Agronomy and Pastures, Fac. of Agric., Sana’a Univ., Yemen \\ E-mail: gkulaib@yahoo.com
}

\begin{abstract}
A survey of weeds of different field crops, orchards and marginal lands were conducted in Bani Al-Hareth area in Sana'a governorate at the High Land region of Yemen, during the period from December 2011 to September 2012. This is to identify and classify the growing weed species in the study area and their spectrum which includes botanical composition, availability, density, coverage and fresh weight. A checklist of weed species found in the area is given. The checklist includes the scientific and vernacular names, life cycle, life forms and availability. Forty-eight weed species belonging to 19 families are reported. Maximum numbers of weed species were belonged to the family Asteraceae followed by Solanaceae, Poaceae and Brassicaceae. Among the recorded species, weed species such as Flaveria trinervia, Tagetes minuta, Chenopodium murale, Salsola kali, Cynodon dactylon, Fagonia indica and Aerva javanica were found to be the most weeds were recorded in all studied lands. Weed plant species in marginal lands had the highest values as compared with those of field crops and orchards ones for most the studied characteristics such as plant density, coverage and fresh weight.
\end{abstract}

Key words: weeds survey, scientific and vernacular name, life cycle, abundance, density, coverage, fresh weight.

\section{Introduction}

Weeds in general can be regarded as the undesirable plants growing in an agricultural area, whether a crop-field or an orchard or fallow land. They are nuisance to agriculture mainly because of their adverse effects on crops yield (Chaudhary and Akram, 1987 and Storkey, 2006). However, not all weeds are unwanted, for instance in range land areas many annual plants are considered as weeds to crops and useful as animal feeds. Weeds represent a widely distributed plant species and biologically important components of most natural and semi-natural ecosystems in the world, such as arable, range lands, forest and aquatic ecosystems.

The losses in crop yield are resulted from weeds competing for water, nutrients uptake, light, space and other ecological resources. Hill (1977), Sen et al. (1984) and Chaudhary (1989) reported that the losses caused by weeds to agriculture are more than losses caused by all other pests. However, weeds and wild plants are still used quite largely by indigenous people in medicine as well as in emergency food supplies. Since weeds occur with wild plants, they are also grazed by livestock as well as wild life which depend largely on natural vegetation.

The Arabian Peninsula in general and Yemen particular, because the geographic location, have floristic elements common with East Africa, African Highlands, Scindo-Saharan region, the Mediterranean region and its own endemics. Moreover, the topography of Yemen lends a great richness in habitats while the elevations from the sealevel to about 3300 meters above sea-level provide different phyto-geographic and agricultural zones. Because of this geographic location of the country, the weed flora is very rich. Whereas, many of the serious weeds here are relatively unknown taxa to most weed specialists in other parts of the world. Little, too, is known about the weed flora in the neighboring countries (Chaudhary and Revri, 1983).

Agriculture plays a crucial role in the economy of Yemen, so that weed surveys are useful for determining the occurrence and importance of weed species in crop production systems. The small-scale farmer in Yemen usually takes it for granted that he will have to spend much of his time hoeing weeds out of his crops. Quite often he will even harvest some of the weeds to supplement the fodder for his livestock. All previous surveys done in the country covered the flora of Yemen (Hepper, 1977; AlHubaishi and Muller-Hohenstein, 1984; Boulos, 1988; Scholte et al., 1991; Gabali, 1995; Wood, 1997; Al-Khulaidi, 2000 and Al-Dubaie, 2004). However, studies on weed flora are still very fragmentary and incomplete. Documentation of weeds flora is, therefore, valuable as grounding knowledge and information for political decision concerning the ecological management of arable land. The earliest modern attempt to study the weeds of Yemen was made by Chaudhary and Revri (1983) who studied weeds of North Yemen. Other papers studied the weed flora of some cultivated lands including; Walter (1981), Al-Gifri et al. (1992), Al-Kathiri (1994), Bawazir et al. (1994) and Al-Kouthayri and Hassan (1998). 
The aim of this study was to contribute towards a better knowledge of the weed plants growing in marginal and cultivated lands of Bani Al-Hareth area. Also to identify and classify the growing weed species in the study area and their spectrum which includes botanical composition, availability, density, coverage and fresh weight.

\section{Materials and Methods}

Field survey of different crops in cultivated lands and non arable lands (marginal lands) were conducted in Bani Al-Hareth area in Sana'a governorate at the High Land region of Yemen, during the period from December 2011 to September 2012.

\section{Studied area:}

Bani Al-Hareth area is located in the North High Land region of Yemen, it is located about $20 \mathrm{~km}$ north of the city of Sana'a (capital of Yemen). The study area lies at latitudes of $15^{\circ} 24^{\prime} \mathrm{N}$ and longitudes of $44^{\circ} 12^{\prime} \mathrm{E}$, with an altitude of 2244 meter above sea-level. In this region, there are two rainy seasons, short season sparsely in March/April and longer season from July to September, but rain may occur sporadically at almost this time of the year, in winter rain is very scare. The mean monthly temperature varies between $12{ }^{\circ} \mathrm{C}$ in December and $25{ }^{\circ} \mathrm{C}$ in July. The maxima and minima ranging from over $30{ }^{\circ} \mathrm{C}$ to $-5{ }^{\circ} \mathrm{C}$ (Al-Hubaishi and MullerHohenstein, 1984).

Bani Al-Hareth area occupies an area of 318.5 $\mathrm{km}^{2}$ (about $31850 \mathrm{ha}$ ), out of this 637 ha is cultivated. The most important agricultural crops cultivated are sorghum, wheat, corn, barley, alfalfa, lentils, faba bean, pea and fruit crops like apple, peach, citrus, grapes, pomegranate, figs and some vegetable crops such as watermelon, cucumbers, tomato, potato, onions, garlic, okra, pepper, chili, cabbage, radish and carrot .... etc.

Seven sites were selected to study the weed flora, namely; Al-Rodeh, Thahban, Karyat Al-Kabel, AlRahaba, Bait-Handal, Gader and Al-Errah. Each site was divided into three locations; field crop lands, orchards lands and marginal lands. Field crop and orchard lands including fields of wheat, sorghum, lentils, faba bean, tomato, onions, garlic, grapes, peach, apple and citrus.

\section{Studied seasons:}

At the studied area, all measurements and weed plant samples were taken in winter (Dry season) and summer (Rainfed season) during the period from December 2011 to September 2012.

\section{Identification of species:}

Plant species were identified at the field and samples from the recorded species were collected and prepared as herbarium sheets after being pressed for voucher identification. Floristic identifications were done by utilization the available taxonomic and floristic literature; Täckholm, Vivi (1974), Chaudhary and Revri (1983), Al-Hubaishi and Muller-Hohenstein (1984) and Scholte et al. (1991). Additionally, local farmers were also interviewed regarding the local vernacular names and distribution pattern of each weed species.

\section{Vegetation measurements:}

According to the reconnaissance method outlined by Mueller-Dombois and Ellenberg (1974), list quadrates method of $20 \mathrm{~m}^{2}$ were used randomly in the studied area over the two studied seasons for plant density and fresh weight. While transect method of $30 \mathrm{~m}$ length in several times were used for determining plant coverage. Shoot parts of annual and perennial weed plants were clipped. Data on the following variables were recorded and averaged over the sampling units to get the mean value within each location by applying the following formulas: Density $\left(\right.$ plant $\left.\mathrm{m}^{-2}\right)=\frac{\text { Number of individual species }}{\text { Total number of quadrates }}$

Coverage $(\%)=$

The area occupied by the species (in unit) $X 100$

The whole investigated area (in unit)

Fresh weight was determined in $\mathrm{g} \mathrm{m}^{-2}$ for the whole stands of such unit area. In addition personal observations were made in the field to note any pertinent events which could help gain better understanding the availability (abundance) based on the ecological characteristics of the weed species into; rare, occasional, frequently and dominant species by using standard method of IUCN (2001).

\section{Statistical analysis:}

The experimental design was Randomized Complete Block Designed (RCBD). Plant measurements were subjected to analysis by $\mathrm{M}$ STAT, C (Russell, 1991). The differences among the means were performed by least significant difference (LSD) at 5\% probability.

\section{Results and discussion}

The present investigation revealed that the weed species of the study area was composed of 48 weed plant species belonging to 19 families of angiosperms. The species were divided into 20 perennials (42\%) and 28 annuals (58\%) as shown in Table (1). Out of the existing and identified 48 weed plant species, Asteraceae represented by 11 species (22\% of individuals), Solanaceae represented by 6 species (12 \% of individuals), Poaceae and Brassicaceae are represented by 5 species (10\% of individuals for each). The remaining 15 families having $46 \%$ of individuals with less than 5 species for each (Fig. 1). 


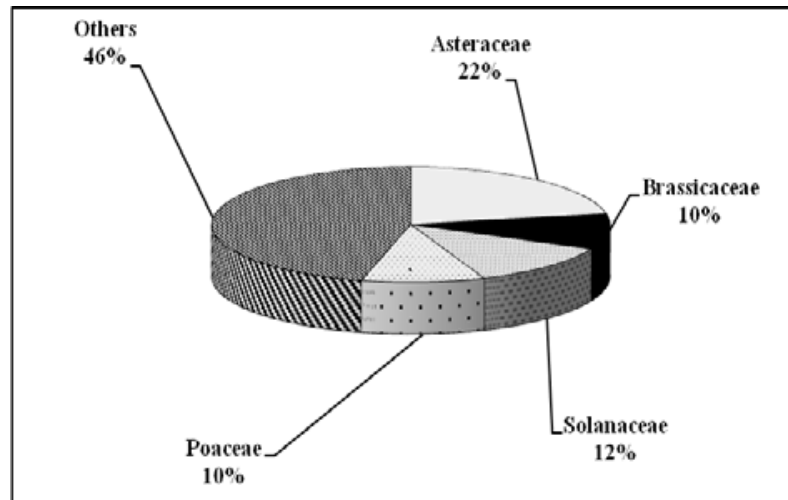

Fig. 1: Weed plant families' percentage in Bani AlHareth area.

More broad leaved weeds were observed than narrow leaved weeds.
More or less similar results were obtained and recorded previously by Chaudhary and Revri (1983) and Al-Seragy (2009).

According to the availability data, weed species can be classified into four categories, 12 species are dominant, 9 are rare, 13 and 16 species are respectively occasionally and frequently available in the investigated area (Table 1). Nine weed species showed low availability, which are rare, included Senecio aegyptius, Cardaria draba, Melilotus alba, Lavandula pubescens and Rumex pulcher. Among the recorded species, weed species such as Flaveria trinervia, Tagetes minuta, Chenopodium murale, Salsola kali, Cynodon dactylon, Fagonia indica and Aerva javanica were found to be the most abundant occurring weed and they were recorded in all studied lands.

Table 1. Botanical composition, life cycle, and availability of weed plant species recorded in Bani Al-Hareth area.

\begin{tabular}{|c|c|c|c|c|}
\hline Family Name & Scientific name & $\begin{array}{c}\text { Vernacular } \\
\text { name }\end{array}$ & $\begin{array}{l}\text { Life cycle } \\
\text { and forms }\end{array}$ & $\begin{array}{c}\text { Availabi } \\
\text { lity }\end{array}$ \\
\hline \multirow{3}{*}{ Amaranthaceae } & Aerva javanica (Burm. f.) Spreng. & Raa & $\begin{array}{c}\text { Perennial } \\
\text { herb }\end{array}$ & Do \\
\hline & Alternanthera pungens Kunth. & Shawk & Annual herb & Fr \\
\hline & Amaranthus hybridus L. & Ro’aaf & Annual herb & $\mathrm{Ra}$ \\
\hline \multirow{11}{*}{$\begin{array}{l}\text { Asteraceae } \\
\text { (Compositae) }\end{array}$} & Conyza linifolia (Willd) Tackh. & Hashish Al-Gabel & Annual herb & Oc \\
\hline & Echinops spinosissimus Turra & Bora’a & $\begin{array}{l}\text { Perennial } \\
\text { herb }\end{array}$ & Oc \\
\hline & Flaveria trinervia (Speng.) Mohr. & Mokhareba & Annual herb & Do \\
\hline & Onopordon arabicum Podl. & $\begin{array}{l}\text { Shawk al- } \\
\text { Hanash } \\
\end{array}$ & $\begin{array}{l}\text { Perennial } \\
\text { herb }\end{array}$ & Oc \\
\hline & Pulicaria jaubertii Gamal El-din. & A'nsif & $\begin{array}{l}\text { Perennial } \\
\text { herb }\end{array}$ & Oc \\
\hline & Pulicaria undulata (L.) Kostel & Jethjath & $\begin{array}{l}\text { Perennial } \\
\text { herb }\end{array}$ & Fr \\
\hline & Reichardia tingitana (L.) Roth. & Moraar & Annual herb & Oc \\
\hline & Senecio aegyptius L. & Sofiraa & Annual herb & $\mathrm{Ra}$ \\
\hline & Sonchus olaraceus L. & Halawmeen & Annual herb & Oc \\
\hline & Tagetes minuta L. & Raymany & Annual herb & Do \\
\hline & Xanthium spinosum L. & Sanaf turk & Annual herb & Do \\
\hline \multirow{4}{*}{$\begin{array}{l}\text { Brassicaceae } \\
\text { (Cruciferae) }\end{array}$} & Brassica nigra (L.) Koch & Khardal & Annual herb & Oc \\
\hline & Cardaria draba (L.) Desv. & Qanbarh & $\begin{array}{l}\text { Perennial } \\
\text { herb }\end{array}$ & $\mathrm{Ra}$ \\
\hline & Diplotaxis erucoides (L.) DC & Halgab & Annual herb & Do \\
\hline & Sisymbrium irrio L. & Fegl Al-Gaml & $\begin{array}{c}\text { Biennial } \\
\text { herb }\end{array}$ & Oc \\
\hline \multirow{3}{*}{ Chenopodiaceae } & Chenopodium murale L. & Zorbeeh & $\begin{array}{c}\text { Annual } \\
\text { Herb }\end{array}$ & Do \\
\hline & $\begin{array}{l}\text { Chenopodium schraderanum Roem. \& } \\
\text { Schult. }\end{array}$ & Aa'thnab & Annual herb & Fr \\
\hline & Salsola kali L. & Sanaf & Annual herb & Do \\
\hline Convolvolaceae & Convolvulus arvensis L. & Faqaa & $\begin{array}{l}\text { Perennial } \\
\text { herb }\end{array}$ & Do \\
\hline Суреraceae & Cyperus rotundus L. & Saeed & $\begin{array}{c}\text { Perennial } \\
\text { herb }\end{array}$ & Oc \\
\hline \multirow{2}{*}{ Euphorbiaceae } & Euphorbia helioscopia L. & Romeed & Annual herb & $\mathrm{Fr}$ \\
\hline & Ricinus communis L. & Tobshua & Perennial & $\mathrm{Fr}$ \\
\hline
\end{tabular}




\begin{tabular}{|c|c|c|c|c|}
\hline & & & Shrub & \\
\hline $\begin{array}{l}\text { Fabaceae } \\
\text { (Leguminosae) }\end{array}$ & Melilotus alba Medik. & Handaqooq & Annual herb & $\mathrm{Ra}$ \\
\hline Fumariaceae & Fumaria judaica Boiss. & Suminah & Annual herb & $\mathrm{Ra}$ \\
\hline $\begin{array}{l}\text { Lamiaceae } \\
\text { (Labiatae) }\end{array}$ & Lavandula pubescens Decne & Fahiya & $\begin{array}{l}\text { Perennial } \\
\text { herb }\end{array}$ & $\mathrm{Ra}$ \\
\hline Malvaceae & Malva parviflora L. & Khobbeiz & Annual herb & Fr \\
\hline Nyctaginaceae & $\begin{array}{l}\text { Commicarpus plumbagineus (Cav.) } \\
\text { Standl }\end{array}$ & Rafraf & $\begin{array}{l}\text { Perennial } \\
\text { herb }\end{array}$ & Fr \\
\hline Orobanchaceae & Orobanche cernua Loefl. & Halook & $\begin{array}{l}\text { Parasites } \\
\text { perennial } \\
\text { herb }\end{array}$ & Oc \\
\hline Papaveraceae & Argemone mexicana L. & Barood & Annual herb & $\mathrm{Fr}$ \\
\hline \multirow{2}{*}{ Plantaginaceae } & Plantago lanceolata L. & Widnah & $\begin{array}{l}\text { Perennial } \\
\text { herb }\end{array}$ & Oc \\
\hline & Plantago major L. & Lissan Al-Kalb & $\begin{array}{l}\text { Perennial } \\
\text { herb }\end{array}$ & Oc \\
\hline \multirow{4}{*}{$\begin{array}{l}\text { Poaceae } \\
\text { (Gramineae) }\end{array}$} & Cynodon dactylon (L.) pers. & Wubal, Zil & $\begin{array}{l}\text { Perennial } \\
\text { grass }\end{array}$ & Do \\
\hline & Eragrostis barrelieri Dav. & Sabool Al-Okaab & Annual grass & $\mathrm{Fr}$ \\
\hline & Pennisetum villosum R. Br. ex Fresen. & Zabad & $\begin{array}{l}\text { Perennial } \\
\text { grass }\end{array}$ & Do \\
\hline & Setarea pumila (poir.) Roem. \& Schult. & Hashish & Annual herb & Oc \\
\hline Polygonaceae & Rumex pulcher L. & Tebaeel & Annual herb & $\mathrm{Ra}$ \\
\hline \multirow{6}{*}{$\square$ Solanaceae } & Datura innoxia Mill & Manj & Annual herb & Oc \\
\hline & Datura stramonium L. & Manj & Annual herb & Fr \\
\hline & Nicotiana rustica L. & Tabg & Annual herb & Oc \\
\hline & Solanum incanum L. & Nugum & $\begin{array}{l}\text { Perennial } \\
\text { shrub }\end{array}$ & Fr \\
\hline & Solanum nigrum L. & Aneb Al-deeb & Annual herb & Oc \\
\hline & Withania somnifera (L.) Dun. & Obab & $\begin{array}{c}\text { Perennial } \\
\text { shrub }\end{array}$ & $\mathrm{Fr}$ \\
\hline \multirow{3}{*}{ Zygophyllaceae } & Fagonia indica Burm. f. & Saha & $\begin{array}{l}\text { perennial } \\
\text { herb }\end{array}$ & Do \\
\hline & Peganum harmala L. & Harmal & $\begin{array}{l}\text { perennial } \\
\text { herb }\end{array}$ & Do \\
\hline & Tribulus terrestris L. & Kotebah & Annual herb & Fr \\
\hline
\end{tabular}

Do, dominant; Fr, frequent; Oc, occasional; Ra, rare.

Plant density is an efficient expression for evaluating numerical strength of species. Significant differences in weed plant density were shown between the different locations, as well as between both seasons (Table 2). Weed plant density had minimum value in field crop lands $\left(10.3\right.$ pls. $\left.\mathrm{m}^{-2}\right)$ as compared with orchard lands and marginal lands, which of 12.7 and 18.9 pls. $\mathrm{m}^{-2}$, respectively. On other words, marginal lands of area exceeded the field crop lands and orchard lands in respect of weed density by more than $45.5 \%$ and $32.8 \%$, respectively as shown in Table (2), this lest finding might be due to the harmful plowing effect on weed plants, leading to lower numbers of such weed plants in cultivated lands (field crops and orchard lands) compared with non arable lands (marginal lands). These findings are in agreement with the study of Al Yemeni (1989), ICARDA (1997), Storkey (2006) and Ture and Bocuk (2008). Availability of weed species is generally decreasing from the last few decades, due to radical changes in various agronomic practices, it is common knowledge that weed flora are affected by changes in crop rotation, increasing depth of plowing, fertilization. mechanization, management strategies and, last but not least, use of herbicides (Sher and Al-Yemeny, 2011). Meanwhile, in dry season weed plant densities dropped to the minimum levels (5.6 pls. $\mathrm{m}^{-2}$ ) as compared with that in rainfed one (22.3 pls. $\left.\mathrm{m}^{-2}\right)$. It may be due to the adequate amounts and even distribution of precipitation during the wet season, in addition to the contribution of the annual plant species associated with the already grown perennial plant species. It should be noted that vegetative growth activities are much dependable on the suitability and convenience of the prevailing of the environmental conditions, since natural plants grow well under the adequate of the available water, moderate temperature.... etc.. Such results have been established by many workers e.g. Ibrahim (1995), 
El-Morsy (2002) and El-Toukhy et al. (2002). The interaction effects of locations and seasons on the density of weed plant species were significant as shown in Table (2). Higher densities of weeds were recorded at marginal lands (31.4 pls. $\mathrm{m}^{-2}$ ) in rainfed season, whereas, the lowest value $\left(5.0\right.$ pls. $\left.\mathrm{m}^{-2}\right)$ was recorded in orchard lands of dry season.

Table 2. Plant density, plant coverage and fresh weight of weed species in different lands in Bani Al-Hareth area during rainfed and dry seasons.

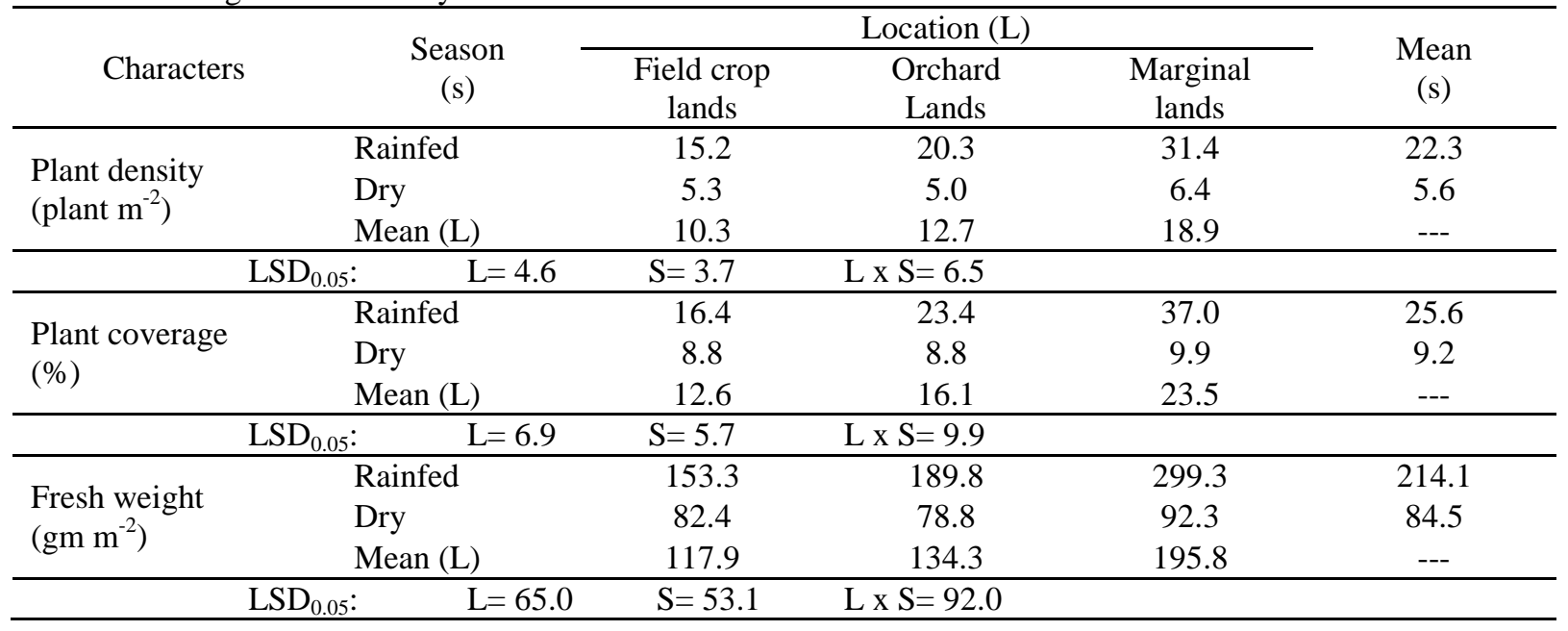

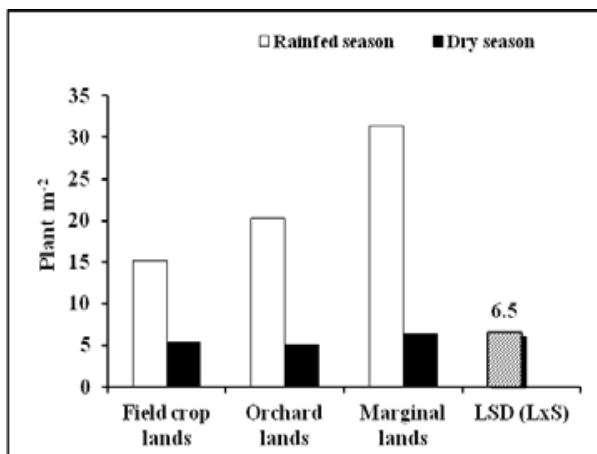

Fig. 2: Plant density $\left(\mathrm{m}^{2}\right)$ of weed plant species in different lands in Bani Al- Hareth area during rainfed and dry seasons.

As shown in Table (2) the weed plant cover percentage varied according to location and season. Cover in marginal lands was greater than that in field crop lands and orchard lands. This was noticed during both seasons (Table 2). Under marginal lands conditions, cover percentage exceeded that in field crop lands and orchard lands by $46.4 \%$ and $31.5 \%$, respectively with significant differences. The differences in weed cover percent between locations should be attributed to the variation between the canopy growth characteristics of individual species and different plant densities. This could be ascribed to effective plowing practices leading to lower weed plant coverage in such lands of fields and orchards. The findings of the present study are in agreement with the study of Moustafa and Alwadi (2010). They reported that crops that are well adapted to their planted areas are often better competitors for weeds since they will tend to occupy a site rapidly. In addition, a close-planted crop will close the canopy more rapidly, reducing the weeds' ability to compete. The results of the present study also showed that weed plant species showed highest coverage in rainfed season (25.6\%) and followed by sharp drop through the dry season (9.2\%) with significant differences (Table 2). Such presented descending sequence in weed coverage percentage should be attributed mostly to the precipitation in wet seasons and to the less degree of drying for the subsequent dry seasons. The present results were in harmony with those reported by Abou-Deya and Salem (1990), Reiad et al. (1996) and Hendawy (2002). The interaction effects of location and season on weed coverage percentage of the grown species was significant. It is worth noting that the greatest record of coverage (37.0 \%) was found at marginal lands in rainfed season, whereas the coverage in each of the field crops and orchard lands of dry season (8.8\%) was the lowest value.

Data in Table (2) showed significant differences in weed fresh weight within the three studied locations of field crop lands, orchard lands and marginal lands with the respective weed fresh weight of $117.9 \mathrm{~g} \mathrm{~m}^{-2}, 134.3 \mathrm{~g} \mathrm{~m}^{-2}$ and $195.8 \mathrm{~g} \mathrm{~m}^{-2}$, respectively. Such value was decreased in cultivated lands of field crops and orchards with great reduction of about $39.8 \%$ and $31.4 \%$, respectively, which might be due to the harmful plowing effect on weed plants, leading to lower weight of such plants. Concerning seasons Table (2) showed that, weed fresh weight was significantly increased in weed plants grown in rainfed season (214.1 $\mathrm{g} \mathrm{m}^{-2}$ ) and decreased in dry season $\left(84.5 \mathrm{~g} \mathrm{~m}^{-2}\right)$, this reduction may be due to the severe lack of precipitation and absence of annual weeds, as well as, the worth edaphic conditions which depressed the biological 
and physiological functions of plants which limited its growth and development.

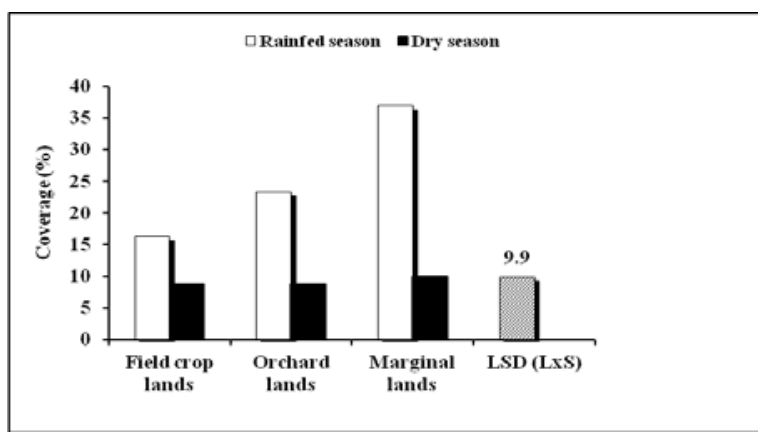

Fig. 3: Plant coverage (\%) of weed plant species in different lands in Bani Al-Hareth area during rainfed and dry seasons.

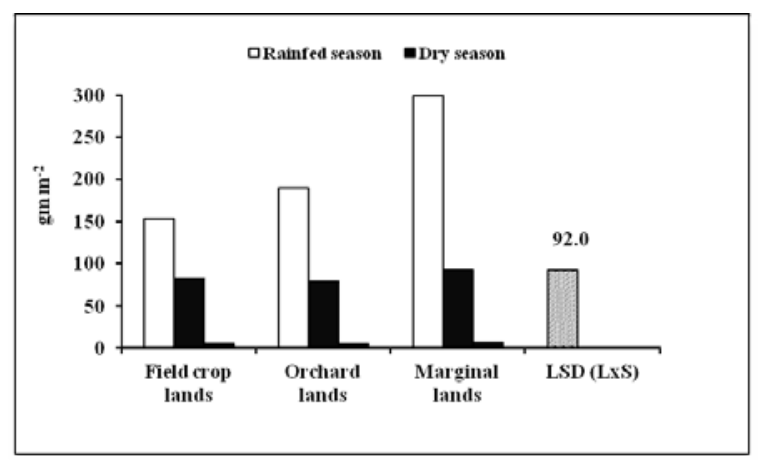

Fig. 4: Fresh weight $\left(\mathrm{gm} \mathrm{m}^{-2}\right)$ of weed plant species in different lands in Bani Al-Hareth area during rainfed and dry seasons.

These results are in line with Dunnett et al. (1998) and El-Morsy (2002). They observed that plant species favored by environmental stress or disturbance were promoted following warm seasons, whereas those favored by more productivity conditions were promoted following a wet growing season. Along the same line, interaction effect of location and season were significant on the fresh weight of weed plant species as shown in Table (2). Results clarified that the highest fresh weight of weed species (299.3 $\mathrm{g} \mathrm{m}^{-2}$ ) was obtained at marginal lands in rainfed season, Whereas, the production in the orchard lands in dry season was the lowest (78.8 $\mathrm{g} \mathrm{m}^{-2}$ ). It could be generally concluded that weed fresh weight were markedly affected by variations in locations and seasons and/or their interaction. In other words, such obtained variations in such trait could be explained by the extreme variations in the prevailing climatic and edaphic conditions within the studied locations and seasons.

\section{References}

Abou-Deya, I. B. and Salem, M. O. (1990). Seasonal variation in the vegetation structure of the protected area at El-Negila. Proc. $4^{\text {th }}$ Conf. Agron., Cairo, II: 679-691.

Al-Dubaie, A. S. (2004). The flora of Yemen (A professional check-list). Environmental Protection Authority, Sana'a, Yemen.

Al-Gifri, A. N; A. H. Abdul Gani and M. F. Salem (1992). Weeds of Delta Abyan, Yemen. A perliment study: Symposium of Fac. of Agric. Univ. of Aden.

Al-Hubaishi, A. and Muller-Hohenstein, K. (1984). An introduction to the vegetation of Yemen. German Agency for Technical Cooperation, GTZ, Germany.

Al-Kathiri, C. R (1994). Weeds: a factor limiting crop production in Yemen. Indian Journal of Plant Protection, 22 (1): 5-8.

Al-Khulaidi, A. A. (2000). Flora of Yemen. Environmental Protection Authority, Sana'a, Yemen, SEMP/ YEM/ 97/100.

Al-Kouthayri, G. R. and Hassan, A. A. (1998). Survey of major weeds in Hadramout Valley, Yemen. Arab Journal of Plant Protection, 16 (1): 19-26.

Al-Seragy, I. M. H. (2009). Studies on the flora of Bani Al-Hareth district in Sana'a governorate with special references to their traditional uses. M.Sc., Thesis, Fac. Science, Sana'a Univ., Yemen.

Al-Yemeni, M. N. (1989). Water use of the alfalfa crop under desert conditions in Saudi Arabia. Ph.D. Thesis, Univ. of Edinburgh, 153p.

Bawazir, A. A.; R. S. Bahian and S. A. Aziz (1994). Weed survey on Tomato fields in Lahej governorate, Yemen. Yemeni-Journal-ofAgriculture-Research, 1 (1): 49-63.

Boulos, L. (1988). A contribution to the flora of South Yemen. Candollea, 43 (2): 549-585.

Chaudhary, S. A. (1989). Grasses of the Saudi Arabia. National Agriculture and Water Research Center, Riyadh, Saudi Arabia, 465p.

Chaudhary, S. A. and Akram, M. (1987). Weeds of Saudi Arabia and the Arabian Peninsula. Regional Agriculture and Water Research Center, Ministry of Agriculture and Water, Riyadh, Saudi Arabia, 246 p.

Chaudhary, S. A. and Revri, A. (1983). Weeds of North of Yemen. German Agency for Technical Cooperation, GTZ, Germany.

Dunnett, N. P.; A. J. Willis; R. Hunt and J. P. Grime (1998). A 38-year study of relations between weather and vegetation dynamics in road verges near Bibury, Gloucestershire. Journal of Ecology, (86): 610-623.

El-Morsy, M. H. (2002). Studies on range plants in Wadi Magid and Wadi Mahgen in the North West Coast of Egypt. Ph.D. Thesis, Fac. Agric., Cairo Univ., Egypt.

El-Toukhy, S. A.; K. M. Ahmed and S. H. Hendawy (2002). Productivity and nutritive value of some associations at Wadi El-Natron El-Almeen road in 
North Western Coast. J. Agric. Sci., Mansoura Univ., 27 (1): 233-244.

Gabali, S. A. (1995). Plant life in Yemen, A general survey and preliminary checklist of the flowering plant species. Series 4, Univ. of Aden, Yemen.

Hendawy, S. H. (2002). Diversity of natural vegetation of Gabal EL- Maghara region, middle Sinai. Minufiya J. Agric. Res., 27 (3): 475-486.

Hepper, F. N. (1977). Outline of the vegetation of Yemen Arab Republic. Cairo Univ., Herb., No. 78: 307-322.

Hill, T. A. (1977). The biology of weeds. The Institute of Biology's Studies in Biology No: 79. Oxford \& IBH Publishing Co. Delhi, Bombay, Calcutta.

Ibrahim, K. A. (1995). Productivity and nutritive value of some range plants of the North Western Coast. M.Sc. Thesis, Fac. Agric. Ain Shams Univ., Egypt.

ICARDA (1997). Conservation and sustainable use of dry land agro-biodiversity of the Fertile Crescent. International Centre for Agricultural Research in the Dry Areas, ICARDA.

IUCN, Species Survival Commission (2001). IUCN Red List Categories, Approved by the $51^{\text {st }}$ Meeting of the IUCN Council. IUCN, Gland, Switzerland.

Moustafa, M. F. M and H. M. Alwadi, (2010). Agrestal and ruderal weeds of some crops in Abha, Saudi Arabia. Journal of Environmental Studies, 5: 15-20.

Mueller-Dombois, D. and Ellenberg, H. (1974). Aims and methods of vegetation analysis., John Wiley \& Sons Inc., New York, U.S.A., 547p.

Reiad, M. Sh.; M. A. Ashoub; I. B. Abou-Deya; M. S. El-Hakeem and K. M. Ahmed (1996). Effect of edaphic and climatic factors on soil and vegetation characters of different associations representative to the North Western Coast of Egypt. Egypt. J. Appl. Sci., 11 (1): 216-231.

Russell, D. F. (1991). MSTAT C. Directory Crop Soil Science Dept., Michigan Univ., USA.

Scholte, P. A.; A. A. Al- Khulaidi and J. J. Kessler (1991). The vegetation of the Republic of Yemen (western part). EPC and ARA, Sana'a and DHV, Amasfoort, Netherlands.

Sen, D. N.; R. K. Mishra and S. Kumar (1984). Yield losses by weeds in the Indian Arid Zone. International Symposium on Weed Biology. Ecol. Syst., 7: 339-346.

Sher, H. and Al-Yemeny, M. N. (2011). Ecological investigation of the weed flora in arable and non arable lands of Al-kharj Area, Saudi Arabia. African Journal of Agricultural Research, 6 (4): 901-906.

Storkey, J. (2006). A functional group approach to the management of UK arable weeds to support biological diversity. Weed Res., 46: 513522.

Täckholm, Vivi (1974). Student's flora of Egypt. Cairo Univ. Pub., Cairo, Egypt.

Ture, C. and Bocuk, H. (2008). Investigation of threatened arable weeds and their conservation status in Turkey. Weed Res., 48: 289-296.

Walter, H (1981). Investigations into the nature and importance of weeds in sorghum in Yemen. Plant Protection Bulletin, Department of Plant Protection, Ministry of Agriculture, Yemen Arab Republic, 2: 13-17.

Wood, J. R. I. (1997). Handbook of the Yemen Flora. Royal Botanic Gardens, Kew, UK. 


\section{حصر لأهم انواع الحشائش النامية في الأراضي الهامشية والأراضي المزروعة في منطقة بني الحارث - صنعاء - اليمن \\ قسم المحاصيل والمراعي - كلية الزراعة - جامعة صنعاء \\ E-mail: gkulaib@yahoo.com}

تم اجراء حصر للحشائش في اراضي المحاصيل الحقلية الدختلفة وأراضي البساتين والأراضي الهامشية في منطقة بني الحارث

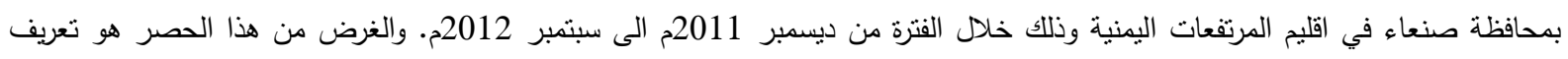
وتقسيم انواع الحشائش النامية في منطقة الدراسة ومعرفة اهم خصائصها التي تثمل التركيب النباتي والوفرة والكثافة النباتية والتغطية والوزن

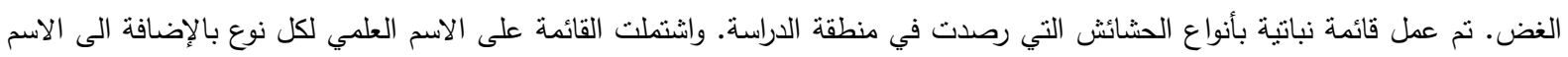

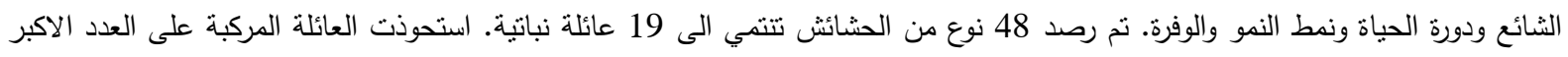

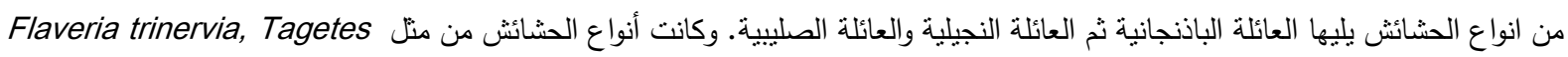
minuta, Chenopodium murale, Salsola kali, Cynodon dactylon, Fagonia indica and Aerva javanica

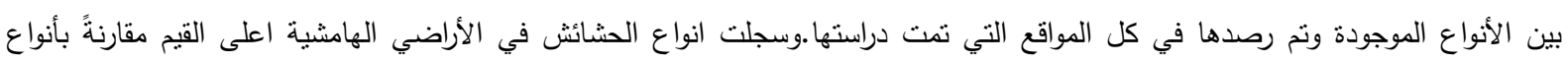
الحثائش في اراضي المحاصيل الحقلية وأراضي البساتين وذلك في معظم الخصائص الددروسة مثل الكثافة النباتية والتغطية والوزن الغضي.

الكلمات الدالة: تعريف وتصنيف الحشائش، دورة الحياة، التركيب النباتي، المرتفعات اليمنية، الوفرة، الكتافة النباتية، التغطية، الوزن الغض . 